\title{
THE PARTICIPATION OF THE PROSECUTOR IN CIVIL PROCEED- INGS AS A GUARANTEE OF ENSURING THE EFFECTIVENESS OF LEGAL PROTECTION. SOME REMARKS
}

\author{
Joanna Misztal-Konecka*
}

\begin{abstract}
The role of the prosecutor in the legal system is traditionally perceived in the context of performing tasks relating to the prosecution of offences and upholding the rule of law. It is worth mentioning, however, that pursuant to Article 7 sentence 1 of the Code of Civil Procedure the prosecutor may petition to institute proceedings in any civil matter as well as participate in any pending proceedings if he considers his presence necessary to protect the rule of law, citizens' rights or social interest. While the broad competence range of the prosecutor in civil proceedings has been assessed with high criticism in the literature on numerous occasions, it is with great caution that one should view possible tendencies towards exclusion of the prosecutor as an attendant of proceedings, without affiliation to either party, when the public interest calls for their participation. Especially in the cases where the court notifies the prosecutor of the need to participate in proceedings, one ought to conclude that it is the moment when the principle of effective legal protection becomes most fully realized through equalizing the litigious position of the parties and prevention of the occurrence of a defect which might invalidate the proceedings. The author postulates transforming notification of the need to participate in proceedings served on the prosecutor into summons for attending it.
\end{abstract}

Key words: prosecutor, civil proceedings, effectiveness of legal protection

* Associate Professor Hab., PhD, John Paul II Catholic University of Lublin, Faculty of Law, Canon Law and Administration, Institute of Law, Department of Civil Procedure, joannamisztal@kul.pl. 


\section{INTRODUCTION}

The role of the prosecutor in the legal system is traditionally perceived in the context of performing tasks relating to the prosecution of offences and upholding the rule of law. It is worth mentioning, however, that in Poland - according to the Law on Prosecutor's Office ${ }^{1}$ - tasks of Prosecutor's Office also include bringing an action in civil cases as well as submitting petitions and participating in court proceedings in civil, labour, and social insurance cases if the protection of the rule of law, social interest, property or citizens' rights so require. Additionally, it is within the Prosecutor's competencies to take measures provided for by law to ensure the correct and consistent application of law in court proceedings. The ordinary legislator therefore perceives the possibility of playing a significant role by a prosecutor's office in broadly understood proceedings in civil cases.

The provisions of the Law on Prosecutor's Office concerning the fulfilment of the Prosecutor's responsibilities in civil proceedings refer to regulations of specific acts and the regulation of the Minister of Justice of 7 April 2016 - Rules of internal procedure of common organisational units of the Prosecutor's Office ${ }^{2}$. In the light of the Code of Civil Procedure, what is crucial for determining the scope of the Prosecutor's activity is Article 7 sentence 1 of the Code of Civil Procedure, pursuant to which the prosecutor may petition to institute proceedings in any matter as well as participate in any pending proceedings if he considers his presence necessary to protect the rule of law, citizens rights or social interest. The aim of the present paper is to analyse only one of the two ways in which the prosecutor can act in civil proceedings $s^{3}$, i.e. the participation of the

${ }^{1}$ Journal of Laws, item 177 as amended.

2 Journal of Laws, item 508 as amended.

3 Cf. in particular: K. Stefko, Udziat prokuratora w postepowaniu cywilnym, Warsaw 1956; E. Wengerek, Udziat prokuratora w postępowaniu cywilnym $w$ świetle polskiej literatury prawniczej, Studia Cywilistyczne 1963, no 3, p. 163-214; W. Masewicz, Prokurator w postępowaniu cywilnym, Warsaw 1975; K. Lubiński, Udziat prokuratora w postępowaniu nieprocesowym w ujęciu prawno-porównawczym, [in:] Proces i prawo. Rozprawy prawnicze. Księga pamiątkowa ku czci Profesora Jerzego Jodtowskiego, (ed.) E. Łętowska, Wrocław-War- 
prosecutor in pending proceedings in the context of the effectiveness of the rulings and the principle of the equality between the parties, according to which the provisions of procedural law regulating the rights and duties of the parties have to-in an identical manner, which ensures fair and equal conditions of conducting a dispute - guarantee both parties effective and identical opportunity to obtain legal protection.

\section{PREREQUISITES FOR THE PARTICIPATION OF THE PROSECUTOR IN CIVIL PROCEEDINGS}

Article 7 of the Code of Civil Procedure specifies which prerequisites justify the participation of the prosecutor in civil proceedings. It lists the need to protect: the rule of law, citizens' rights, and social interest.

The protection of the rule of law is understood as social relations in their entirety which are regulated by law, principles developed in the applicable legal system - it is rightly recognized to be a superior prerequisite for the participation of the prosecutor in civil proceedings ${ }^{4}$.

saw 1989, p. 139-155; W. Broniewicz, Prokurator w cywilnym postepowaniu kasacyjnym, Prokuratura i Prawo 1997, no 9, p. 14-19; P. Wiśniewski, Udziat prokuratora w postępowaniu cywilnym. Część I, Prokuratura i Prawo 1997, no 10, p. 62-73; Część II, Prokuratura i Prawo 1997, no 11, p. 57-78; M. Kozaczek, Prokurator w postępowaniu upadtościowym, Prokuratura i Prawo 2005, no 5, p. 82-94; T. Zembrzuski, Rola Prokuratora Generalnego w cywilnym postępowaniu kasacyjnym, Prokuratura i Prawo 2006, no 2, p. 151-162; B. Deskiewicz, Udziat prokuratora $w$ postępowaniu o zaprzeczenie pochodzenia dziecka poczętego w drodze sztucznej inseminacji heterologicznej, Prokuratura i Prawo 2007, no 9, p. 107-117; Z. Zawadzka, Formy udziatu prokuratora w postępowaniu cywilnym, Prokuratura i Prawo 2009, no 10, p. 85-103; Z. Zawadzka, Pozycja procesowa prokuratora $w$ postepowaniu cywilnym, Prokuratura i Prawo 2010, no 6, p. 126-136; A. Jaworski, Legitymacja prokuratora do ztożenia wniosku o zmiane postanowienia w przedmiocie obowiazku poddania się leczeniu odwykowemu. Glosa do postanowienia z dnia 9 października 2009 r. (IV CSK 210/09), Przegląd Sądowy 2011, no 5, p. 116-121; P. Wiśniewski, Udziat prokuratora w postępowaniu cywilnym, Toruń 2014; A. Franusz, Dokonywanie czynności dyspozytywnych o charakterze materialnym $w$ procesie z powództwa prokuratora na rzecz oznaczonej osoby, Prokuratura i Prawo 2016, no 9, p. 109-130.

4 B. Bladowski, Metodyka pracy sędziego cywilisty, (ed.) 3, Warsaw 2009, p. 137; P. Wiśniewski, Udziat prokuratora w postępowaniu cywilnym, Toruń 2014, p. 55; M. Sycho- 
The protection of citizens' rights becomes the prosecutor's present objective when individuals - due to specific obstacles - are not able to protect their rights by themselves or it is necessary to resolve a legal problem raising particular concerns or one which is precedentials.

Finally, Article 7 of the Code of Civil Procedure mentions the protection of social interest ${ }^{6}$, i.e. the protection of the common good (public interest), which finds its axiological justification in Articles 1 and 2 of the Constitution of the Republic of Poland, which state that the Republic of Poland shall be the common good of all its citizens and a democratic state ruled by law and implementing the principles of social justice.

It is generally acknowledged that a decision to institute or to join the proceedings is taken by the prosecutor independently and it is not subject to judicial review ${ }^{7}$ and, most importantly, there are no grounds to acknowledge that the court is competent to dismiss an action (petition) brought by the prosecutor due to the lack of prerequisites referred to in Article 7 of the Code of Civil Procedure. The position of the prosecutor in a dispute is based on his locus standi referred to in the literature as public-law standing to sue 8 .

Pursuant to Article 60 of the Code of Civil Procedure, the prosecutor may join the proceedings at any stage. The prosecutor's statement on joining the proceedings must be explicit, while prior notification of pending proceedings itself served on the prosecutor (service of a copy of a peti-

wicz, [in:] Kodeks postępowania cywilnego. Tom I. Komentarz. Art. 1-366, (ed.) A. Marciniak, K. Piasecki, (ed.) 7, Warsaw 2016, p. 93.

${ }^{5}$ M. Sychowicz, [in:] Kodeks postępowania cywilnego. Tom I. Komentarz. Art. 1-366, (ed.) A. Marciniak, K. Piasecki, (ed.) 7, Warsaw 2016, p. 93.

6 P. Wiśniewski, Udziat prokuratora w postępowaniu cywilnym, Toruń 2014, p. 55.

7 Inter alia: B. Bladowski, op.cit., p. 137; M. Sychowicz, [in:] Kodeks postępowania cywilnego. Tom I. Komentarz. Art. 1-366, (ed.) A. Marciniak, K. Piasecki, (ed.) 7, Warsaw 2016, p. 94, 270-272.

8 See: judgment of the Court of Apeal in Lublin of 10 December 2013, I ACa 587/13, LEX 1416187; judgment of of the Court of Apeal in Cracow of 12 January 2016, I ACa 1332/15, LEX 2004520; judgment of of the Court of Apeal in Eódź of 18 February 2016, I ACa 775/15, LEX 2005581; judgment of the Court of Apeal in Wrocław of 1 March 2012, I ACa 111/12, LEX 1130913; judgment of the Supreme Court of 2 August 2007, V CSK 109/07, OSNC 2008/9/107; judgment of the Supreme Court of 3 February 1999 r., III CKN 167/98, LEX 483310. 
tion or notification of the date of hearing) do not make him the participant in the proceedings 9 . The appearance of the prosecutor in pending proceedings neither means that the prosecutor acts as a plaintiff nor that he remedies the lack of locus standi of the plaintiff in non-contentious proceedings ${ }^{10}$. What is more, the prosecutor can stop participating in the proceedings that he joined. It requires, however, the prosecutor's explicit statement filed with the court where the prosecutor states that he considers his role redundant ${ }^{11}$.

\section{THE RIGHT OR DUTY OF THE PROSECUTOR TO PARTICIPATE IN CIVIL PROCEEDINGS IN THE CASE OF BEING NOTIFIED UNDER ARTICLE 59 OF THE CODE OF CIVIL PROCEDURE?}

Another issue that I would like to analyse is the relation between Articles 7 and 59 of the Code of Civil Procedure. Pursuant to the first Article, the participation of the prosecutor in civil proceedings is conditioned by the requirement to protect the rule of law, citizens' rights or social interest. Whereas, pursuant to Article 59 of the Code of Civil Procedure, the court shall notify the prosecutor of any cases where the court deems the prosecutor's presence necessary.

The court conducting civil proceedings should notify the prosecutor if the court deems that prerequisites referred to in Article 7 of the Code of Civil Procedure justify the participation of the prosecutor in a specific case. It is exclusively for the court to decide whether the prosecutor needs

9 Decision of the Supreme Court of 23 December 1968, I PZ 67/68, LEX 6434; decision of the Supreme Court of 4 March 1969, II CR 20/69, OSNPG 1969/6/44; decision of the Supreme Court of 2 October 2003, V CZ 88/03, LEX 84308. See also: M. Sychowicz, [in:] Kodeks postępowania cywilnego. Tom I. Komentarz. Art. 1-366, (ed.) A. Marciniak, K. Piasecki, (ed.) 7, Warsaw 2016, p. 97.

${ }_{10}$ Decision of the Supreme Court of 7 January 1966, I CR 371/65, OSNC 1966/78/133; judgment of the Supreme Court of 10 February 1972, II CR 663/71, OSNC 1972/7-8/148.

${ }^{11}$ Decision of the Supreme Court of 8 November 1963, I PZ 48/63, OSNC $1964 / 6 / 126$. 
to participate in specific proceedings. The court's decision is based on the factual circumstances of the case and legal assessment, especially the assessment of the nature and degree of complexity of legal problems. It is rightly acknowledged that the failure of the court to notify the prosecutor does not deprive the party of its rights (it does not constitute the grounds for the invalidity of proceedings), whereas a potential violation of Article 59 of the Code of Civil Procedure is, in principle, an infringement of procedural law, therefore the effectiveness of this charge requires showing the impact of an infringement on the content of the issued adjudication ${ }^{12}$.

A different assessment - according to the position of the Supreme Court - is justified solely by those special cases in which the court will notice that the party to court proceedings, which does not have a legal representative for the purposes of litigation, shows signs of mental disturbances preventing it from taking conscious and free action in proceedings ${ }^{13}$. To my mind, physical deficiencies which prevent action (e.g. quadriplegia, coma) should be treated equally with mental health problems. Then, the court is obliged to notify the prosecutor of pending proceedings so that he can join a case and/or file a petition to incapacitate such a person.

The above conclusions clearly point to the need to address a key question, i.e. whether the prosecutor - notified under Article 59 of the Code of Civil Procedure by the court of a specific civil case where the court deems his presence necessary - is competent to consider his presence redundant.

According to a position which prevails in the literature and rulings, a notification of the need to participate in the proceedings which is served on the prosecutor is not binding on him and he is competent to decide, at

12 Judgment of the Supreme Court of 13 June 1997, I CKN 182/97, LEX 50612; decision of the Supreme Court of 14 January 2008, II PK 259/07, LEX 864115; judgment of of the Court of Apeal in Katowice of 7 March 2014, I ACa 1175/13, LEX 1466784. See also M. Sychowicz, [in:] Kodeks postępowania cywilnego. Tom I. Komentarz. Art. 1-366, (ed.) A. Marciniak, K. Piasecki, (ed.) 7, Warsaw 2016, p. 270.

13 Resolution of the Supreme Court of 12 December 1960, I CO 25/60, OSNCK 1961/2/32; judgment of the Supreme Court of 6 February 1969 r., III CRN 403/68, LEX 6451; judgment of the Supreme Court of 16 July 1971, III CRN 187/71, LEX 6961; decision of the Supreme Court of 8 October 1998, II CKN 903/97, LEX 1216978; judgment of the Supreme Court of 6 April 2005, III CK 319/04, LEX 175997. Cf. W. Masewicz, op.cit., p. 121; M. Sychowicz, [in:] Kodeks postępowania cywilnego. Tom I. Komentarz. Art. 1-366, (ed.) A. Marciniak, K. Piasecki, (ed.) 7, Warsaw 2016, p. 269. 
his discretion, whether there are prerequisites referred to in Article 7 of the Code of Civil Procedure to take part in the proceedings, which in practice means that - even though the court deems the prosecutor's presence in specific proceedings necessary - he can refuse to join these proceedings ${ }^{14}$. A different opinion was expressed by M. Stypułkowska and S. Gross who hold that the assumption that a notification under Article 59 of the Code of Civil Procedure is not binding on the prosecutor is at variance with the purposes of the prosecutor's participation in the civil proceedings as well as the implementation of the main principles of these proceedings ${ }^{15}$.

At the same time, it is worth mentioning that in the literature and rulings it was considered impossible for the prosecutor not to take action in spite of correct notification of the need to participate in the proceedings served on him by the court ${ }^{16}$. Suffice it to say that such cases have occurred in practice. This happens despite the fact that pursuant to $\$ 360$ section 2 of rules of internal procedure of common organisational units of the Prosecutor's Office: The prosecutor declares his participation in the proceedings he was notified of by the court pursuant to Article 59 of the Code of Civil Procedure; the failure to declare participation in such a case may happen only in exceptional circumstances.

${ }_{14}$ See especially resolution of the Supreme Court of 24 June 1966, III CZP 42/66, OSNC 1966/12/210; judgment of the Supreme Court of 10 February 1972, II CR 663/71, OSNC 1972/7-8/148; judgment of the Court of Apeal in Lublin of 10 December 2013, I ACa 587/13, LEX 1416187. Cf. K. Stefko, op.cit., p. 85; W. Masewicz, op.cit., p. 122-123; P. Wiśniewski, Udziat prokuratora w postępowaniu cywilnym. Część I, Prokuratura i Prawo 1997, nr 10, p. 72-73; Z. Zawadzka, Formy ..., p. 93; P. Wiśniewski, Udziat prokuratora w postępowaniu cywilnym, Toruń 2014, p. 60-62; M. Sychowicz, [in:] Kodeks postępowania cywilnego. Tom I. Komentarz. Art. 1-366, (ed.) A. Marciniak, K. Piasecki, (ed.) 7, Warsaw 2016, p. 94, 270; M. Jędrzejewska, P. Grzegorczyk, [in:] Kodeks postępowania cywilnego. Komentarz. Tom I. Postępowanie rozpoznawcze, (ed.) T. Ereciński, (ed.) 5, Warsaw 2016, p. 190, 379; E. Rudkowska-Ząbczyk, Komentarz do art. 59, [in:] Kodeks postępowania cywilnego. Komentarz, (ed.) E. Marszałkowska-Krześ, (ed.) 8, Warsaw 2017 (Legalis).

15 M. Stypułkowska, Zakres uprawnień prokuratora $w$ postępowaniu cywilnym, Nowe Prawo 1957, no 2, p. 67-69; S. Gross, Glosa [do wyroku Sądu Najwyższego z dnia 10 lutego 1972 r., II CR 663/71], Orzecznictwo Sądów Polskich i Komisji Arbitrażowych 1972, no 12 , p. 543.

${ }_{16}$ Resolution of the Supreme Court of 12 December 1960, I CO 25/60, OSNCK 1961/2/32; P. Wiśniewski, Udziat prokuratora w postępowaniu cywilnym, Torun 2014, p. 177. 
Despite the reservations expressed by $S$. Gross being right, I must share the opinion that notifying the prosecutor of the necessity to participate in the civil proceedings is not binding on him. The prosecutor is competent not to declare his participation. The validity of such a position is confirmed already by a basic method of interpretation-a linguistic one. Verba legis, the court notifies the prosecutor just as it notifies a person for whose benefit the prosecutor brought an action (Article $56 \$ 1$ of the Code of Civil Procedure), notifies a person who should appear in the case in the capacity of a plaintiff (Article $196 \$ 1$ of the Code of Civil Procedure) ... etc. Clearly, it is a different type of notification than summoning a person as defendant (Article 198 of the Code of Civil Procedure). It is worthwhile posing another question, i.e. whether this provision - regarding notifying, not summoning, the prosecutor to participate in the civil proceedings - should be changed and, if yes, what should be the direction of this amendment.

\section{ABOUT THE IMPORTANCE OF THE PROSECUTOR'S PARTICIPATION}

IN CIVIL PROCEEDINGS - APPROVINGLY

The broad competence range of the prosecutor in civil proceedings has been assessed with high criticism in the literature on numerous occasions by stating that an element of the right to a fair trial is not only in enabling a subject to present the case in court but also prohibition of encroaching upon their legal sphere by third parties through, for instance, bringing an action or appealing on a ruling ${ }^{17}$. While this stance can be, in my opinion,

${ }_{17}$ Cf. especially A. Jaworski, Uprawnienia prokuratora w postępowaniu cywilnym w przysztym Kodeksie postępowania cywilnego - propozycja podstawowych zatożeń, [in:] Postępowanie rozpoznawcze w przysztym Kodeksie postepowania cywilnego, (ed.) K. Markiewicz, (ed.) A. Torbus, Warsaw 2014, p. 497-500; A. Kościółek, A. M. Arkuszewska, Udziat prokuratora $w$ postępowaniu cywilnym. Uwagi de lege lata $i$ de lege ferenda, [in:] Postępowanie rozpoznawcze w przysztym Kodeksie postępowania cywilnego, (ed.) K. Markiewicz, (ed.) A. Torbus, Warsaw 2014, p. 529-547; K. Gajda-Roszczynialska, Udziat podmiotów innych niż materialnie uprawnione jako stron $w$ procesie cywilnym a kryterium interesu prawnego zagadnienia wybrane, Polski Proces Cywilny 2015, no 3, p. 369-370. 
upheld in principle with regard to the prosecutor's participation in the capacity of the party, it is with great caution that one should view possible tendencies towards exclusion of the prosecutor as an attendant of proceedings, without affiliation to either party, when the public interest calls for their participation.

It is then worthwhile to pay attention to regulations in Article 59 of the Code of Civil Procedure, but this time to notice it not so much as a means of initiating unjustified intrusion of the prosecutor in the sphere of private matters, but a guarantee of effective legal protection. Even a cursory analysis of judicial practice proves that the number of civil cases in which the court notifies the prosecutor that their participation is deemed necessary is negligible. This allows for attempting an explanation of this phenomenon: either civil law courts do not appreciate the importance of the prosecutor's participation in proceedings or they notify the prosecutor about the need to attend it only in exceptional circumstances when other judicial means do not suffice to ensure appropriate course of court proceedings. The latter explanation is definitely closer to my stance and its implications will be addressed later on during my presentation.

At this point it should be remembered that the prosecutor, joining the proceedings, is not obliged to indicate which party he shall join. The prosecutor is not affiliated to either party. In accordance with his own judgement, he may submit statements and motions which he considers pertinent, convey his opinion on the outcome of hearing the evidence and the legal position of the parties along with comments on the course of the proceedings. The position of the prosecutor who joined pending civil proceedings is thus independent, though doctrinally his position is sometimes interpreted by applying a distant analogy to an intervening party ${ }^{18}$. And it is exactly the independence of the prosecutor's position, directed at the protection of the rule of law, citizens' rights and social interest, that may guarantee effective legal protection.

In order not to make unfounded arguments, it appears pertinent to furnish an example of a situation in which such qualification of the prosecutor's participation in proceedings can be constructed. Such an example

${ }_{18}$ M. Sychowicz, [in:] Kodeks postępowania cywilnego. Tom I. Komentarz. Art. 1-366, (ed.) A. Marciniak, K. Piasecki, (ed.) 7, Warsaw 2016, p. 93. 
is offered by the rulings of the Supreme Court, which concluded that the prosecutor notified of proceedings whose party is a person without actual capacity to perform actions in court proceedings on account of psychological or physical disturbances, must be the guarantor of assuring the integrity of such a person's interests: in the first place as an entity empowered to submit a petition for this person's legal incapacitation and then as the party to the proceedings under Article 7 of the Code of Civil Procedure ${ }^{19}$. What is more, the view is also expressed in the rulings of the Supreme Court that hearing a case - without notifying the prosecutor - of a person with mental illness who - on account of illness - is incapable of conscious judgements and has no appointed legal representative for litigation deprives the said person of the possibility to defend their rights, which renders such proceedings invalid (Article 379 point 5 of the Code of Civil Procedure) ${ }^{20}$.

Despite the fact that the number of cases with the participation of persons without legal incapacitation yet suffering from mental or physical disorders, whose disability is an actual impediment to performing procedural actions (and thus to defending their rights in court) is truly insignificant (negligible), it would be unacceptable to marginalize or just disregard the difficulties occurring in it, since such persons too have the right to legal protection. It would be contrary to the elementary sense of justice to accept a situation where the party possessing legal capacity, yet on account of obstacles of legal or factual character being unable to exercise it and having no legal representative, was deprived of the possibility to defend their rights. It would contradict the principle of fair trial if the court and other authorities were deemed as not obliged to undertake actions intended to ensure actual realization of the principle of the equality of parties under the law, including the participation of the person whom the proceedings concern, hearing them (audiatur et altera pars), if a litigant (plaintiff, defendant, attendant of non-litigious proceedings, etc.) on account of obstacles of mental or physical character does not possess in practice the capability of participating in proceedings.

19 Decision of the Supreme Court of 4 March 1958, III CZ 9/58, LEX 1632081; judgment of the Supreme Court of 16 July 1971, III CRN 187/71, LEX 6961; decision of the Supreme Court of 8 October 1998, II CKN 903/97, LEX 1216978.

20 Judgment of the Supreme Court of 6 April 2005, III CK 319/04, LEX 175997. 
As the problem of the lack of real possibility to exercise the capability to litigate is not considered on the grounds of its absence or reduced litigation capability but on the grounds of ensuring the possibility of appropriate defense of its rights, the participation of the spokesman of public interest, whom the prosecutor embodies, achieves appropriate significance, especially in the context of ensuring the possibility of defending the rights of the said litigant. Then the participation of the prosecutor in civil proceedings constitutes a "safety valve" and creates a greater guarantee of achieving effective proceedings, manifested through provision of factual legal protection ${ }^{21}$.

Additionally it ought to be stressed here that the right to a fair trial is of material character, hence the effectiveness of legal protection should ensure not only access to court or verifying legitimacy of the claims from the parties in valid court proceedings but also guarantee the binding force of court adjudication ${ }^{22}$. Consequently the prosecutor's participation as a precaution against rendering the proceedings invalid comes to be viewed as a remedy preventing adjudication from being revoked or proceedings from being reinstated on the grounds of invalidity ${ }^{23}$. The admissibility of prosecutor's participation in civil proceedings is thus justified in the view of the prosecutor's office, which is to safeguard both public and private interests.

\section{SUMMARY}

By summary, the effectiveness of court proceedings is understood as a feature of proceedings which allows for realization of the legal guarantee to just adjudication in a given case without unjustified delay. Apart from the postulate of prompt proceedings (issuing the verdict in a reasonable time) it includes the possibility of actual enjoyment of legal protection. On the grounds of international and constitutional legal regulations the

21 W. Masewicz, op.cit., p. 42.

22 See especially A. Łazarska, Rzetelny proces cywilny, Warsaw 2012, chapter XII.

23 P. Wiśniewski, Udziat prokuratora w postępowaniu cywilnym, Toruń 2014, p. 178. 
binding force of adjudication as a guarantee of the effectiveness of legal protection becomes particularly important. Due to its existence the party has assurance of enforceable, not only illusory legal protection, whose stability and certainty cannot be undermined by temporariness or changeability of the legal protection system.

Despite the increasing propagation of the stance whereby civil proceedings serve only to protect private interests, hence the participation of state bodies is not desired, on the basis of the conducted analysis we may not fail to notice the need for retaining prosecutor's authorization to participate in civil proceedings. Especially in the cases where the court notifies the prosecutor of the need to participate in proceedings, one ought to conclude that it is the moment when the principle of effective legal protection becomes most fully realized through equalizing the litigious position of the parties and prevention of the occurrence of a defect which might invalidate the proceedings. Hence currently in the relation between Article 7 and Article 59 of the Code of Civil Procedure the existence of gross inconsistency can be ascertained. Although attempts to remove it were made during the construction of rules of internal procedure of common organizational units of the Prosecutor's Office, they are still insufficient. De lege ferenda one ought to postulate transforming notification of the need to participate in proceedings served on the prosecutor into summons for attending it. The court decision issued in the manner of Article 59 the Code of Civil Procedure constitutes on the one hand the expression of profound knowledge about the realities of given proceedings while on the other hand it is issued only in exceptional cases in which the existing procedural regulations are insufficient to ensure the validity of litigation. Secondly, such a change would remove a potential possibility of ignoring a court decision by a prosecutor, which compromises both the authority of the court and prosecutor.

\section{REFERENCES:}

Bladowski Bogdan, Metodyka pracy sędziego cywilisty, (ed.) 3, Warsaw 2009. Broniewicz Witold, Prokurator w cywilnym postępowaniu kasacyjnym, Prokuratura i Prawo 1997, no 9. 
Deskiewicz Bartosz, Udziat prokuratora w postępowaniu o zaprzeczenie pochodzenia dziecka poczętego $w$ drodze sztucznej inseminacji heterologicznej, Prokuratura i Prawo 2007, no 9.

Franusz Anna, Dokonywanie czynności dyspozytywnych o charakterze materialnym $w$ procesie z powództwa prokuratora na rzecz oznaczonej osoby, Prokuratura i Prawo 2016, no 9.

Gajda-Roszczynialska Katarzyna, Udziat podmiotów innych niż materialnie uprawnione jako stron $w$ procesie cywilnym a kryterium interesu prawnego - zagadnienia wybrane, Polski Proces Cywilny 2015, no 3.

Gross Stanisław, Glosa [do wyroku Sądu Najwyższego z dnia 10 lutego 1972 r., II CR 663/71], Orzecznictwo Sądów Polskich i Komisji Arbitrażowych 1972, no 12 .

Jaworski Adam, Legitymacja prokuratora do ztożenia wniosku o zmiane postanowienia w przedmiocie obowiazku poddania się leczeniu odwykowemu. Glosa do postanowienia z dnia 9 października 2009 r. (IV CSK 210/09), Przegląd Sądowy 2011, no 5.

Jaworski Adam, Uprawnienia prokuratora w postępowaniu cywilnym w przysztym Kodeksie postępowania cywilnego - propozycja podstawowych zatożeń, [in:] Postępowanie rozpoznawcze w przysztym Kodeksie postępowania cywilnego, (ed.) Krystian Markiewicz, (ed.) Andrzej Torbus, Warsaw 2014.

Kodeks postępowania cywilnego. Komentarz, (ed.) Elwira Marszałkowska-Krześ, (ed.) 8, Warsaw 2017 (Legalis).

Kodeks postępowania cywilnego. Komentarz. Tom I. Postępowanie rozpoznawcze, (ed.) Tadeusz Ereciński, (ed.) 5, Warsaw 2016.

Kodeks postępowania cywilnego. Tom I. Komentarz. Art. 1-366, (ed.) Andrzej Marciniak, Kazimierz Piasecki, (ed.) 7, Warsaw 2016.

Kościółek Anna, Arkuszewska Aneta M., Udziat prokuratora w postępowaniu cywilnym. Uwagi de lege lata $i$ de lege ferenda, [in:] Postępowanie rozpoznawcze w przysztym Kodeksie postepowania cywilnego, (ed.) Krystian Markiewicz, Andrzej Torbus, Warsaw 2014.

Kozaczek Marcin, Prokurator w postępowaniu upadtościowym, Prokuratura i Prawo 2005, no 5.

Lubiński Kazimierz, Udziat prokuratora $w$ postępowaniu nieprocesowym $w$ ujeciu prawno-porównawczym, [in:] Proces i prawo. Rozprawy prawnicze. Ksiegga pamiątkowa ku czci Profesora Jerzego Jodtowskiego, (ed.) Ewa Łętowska, Wrocław-Warsaw 1989.

Łazarska Aneta, Rzetelny proces cywilny, Warsaw 2012.

Masewicz Walery, Prokurator w postępowaniu cywilnym, Warsaw 1975. 
Stefko Kamil, Udziat prokuratora w postępowaniu cywilnym, Warsaw 1956.

Stypułkowska Maria, Zakres uprawnień prokuratora w postępowaniu cywilnym, Nowe Prawo 1957, no 2.

Wengerek Edmund, Udziat prokuratora w postępowaniu cywilnym w świetle polskiej literatury prawniczej, Studia Cywilistyczne 1963, no 3.

Wiśniewski Paweł, Udziat prokuratora w postępowaniu cywilnym, Toruń 2014.

Wiśniewski Paweł, Udziat prokuratora w postępowaniu cywilnym. Część I, Prokuratura i Prawo 1997, no 10; Część II, Prokuratura i Prawo 1997, no 11.

Zawadzka Zofia, Formy udziatu prokuratora w postępowaniu cywilnym, Prokuratura i Prawo 2009, no 10.

Zawadzka Zofia, Pozycja procesowa prokuratora w postępowaniu cywilnym, Prokuratura i Prawo 2010, no 6.

Zembrzuski Tadeusz, Rola Prokuratora Generalnego w cywilnym postępowaniu kasacyjnym, Prokuratura i Prawo 2006, no 2. 